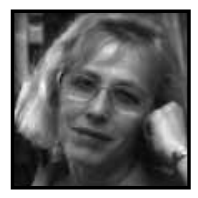

\title{
Working With a Student Model in a Creative Non-Fiction Workshop: Charging Joint Creativity
}

Carol Lipszyc, State University of New York, Plattsburgh

\section{ABSTRACT}

In this arts-based inquiry, I examine how a student model creative non-fiction essay develops students in a third-year creative writing workshop as critical readers, editors, and writers. Over the course of two semesters, student writers reciprocally acquire strategic knowledge and enhance their creativity. Plural voices emerge in the dialogue between the model student/writer, her peers, and my curriculum as evidenced in the narrative excerpts composed and revised by the student; in her peers' critical feedback; and in students' reflections. Exploring this collaboration, I envision affording more opportunity for student model writers to share their evolving knowledge in both traditional and online classrooms.

\section{Introduction}

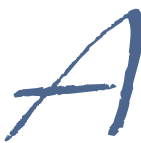

$s$ a teacher of expressive writing and practitioner of the writing arts, I search for ways to trigger my students' creativity and prepare them with a repository of strategies so they can become autonomous writers who will shape their own future writing communities. There is a dichotomy at work here: I aim to create conditions in a writing classroom that will foster a student's individuality while connecting that student to a network of relationships. Including student models as part of my reading component has proven to be an instrumental step in my quest. One student model, the focus of this study, was a dynamic vehicle for just such student growth. 
Two questions drive the inquiry: How would reading a student model nurture the individual writer and enhance creativity in a collaborative setting that is the college creative writing workshop? Secondly, what strategic knowledge will students gain from one another? I hope to present an illustration of a partnership, what Fritjof Capra (1996) characterizes as "pervasive cooperation" between my classroom student writers and the student model writer, as they promote their development and alternate teaching and learning roles.

In the fall of 2008, I taught an introductory third-year creative non-fiction course, open to all students who had completed their requisite composition credits. The course is generally capped at twenty-two; students enroll both from the writing program and from programs across disciplines here in this North Country liberal arts college, which is part of the SUNY system. The original model, "Cocoon," was written by a student, D. Andrews, ${ }^{1}$ in the first semester. With her permission, I then included that essay in the second semester curriculum (Spring 2009) as a model in the thematic units of family story and writer interacting with nature. Second semester students studied and mimicked facets of the model and, importantly, provided constructive feedback to D. Andrews, thereby reciprocally sharing and intelligently applying new knowledge to their respective writing.

This inquiry rests on systemic thinking. I build in this inquiry on Fritjof Capra's call for relatedness, insofar as it applies to the teaching of creative writing (Lipszyc, 2006). Teaching and writing are complex epistemologies; I value the movement between systems of thought as I decode the intricate processes of these two practices.

To think systemically as writer/teacher/researcher:

a) I think in terms of interconnectedness; meaning I derive in this inquiry will come from the experience of context (Capra, 2004);

b) I search for a non-linear, non-hierarchical understanding of relationships within the whole (Capra, 1999).

In my adherence to a non-linear, non-hierarchical view of teaching writing, I describe a cyclical exchange which arises in a number of contexts in this inquiry. These contexts include: student model, D. Andrews' influence on the 2009 classroom of student writers; feedback from that classroom community back to the student model writer; and students' reflections during the process. Leadership in this context was systemic, shared, with responsibility extended to the whole. As a teacher, I acted as a leader of shared processes that empowered students (Capra, 2002; Dewey, 1938). 


\section{Impress of the Student Model}

I design writing courses where reading and writing have equal footing and where students become better writers by example, namely, by reading the exemplary work of those writers who preceded them (Murray, 1989; Prose, 2006). Along with an eclectic variety of professional models ranging from Amy Tan, Annie Dillard, Bruce Chatwin, and Lee Gutkind, I present student models for reading material in thematic units. I integrate a select number of these student model essays to challenge students with material just beyond their grasp but not too removed from their needs, drawing from Vygotsky's (1978) zone of proximal development. Applying this theory to the teaching of creative writing, I afford students the space to critically ask questions about the model and their own writing; to glean significance from their new experience and act upon it with newfound maturity; and to build strategic knowledge with other students. My goal is that any number of these models will inspire students who might apply or mimic in their writing some figurative trope or rhetorical pattern from that model.

As Barone (2000) informs, the needs of my students and the writing environment press upon and shape each other. When, in 2009, I conducted a semi-structured interview with one of my students, Jerome, about the comparative educational value of using both student and professional models, he spoke frankly of the apprehensions he faced and about how D. Andrews buoyed his self-confidence. Jerome had returned to school after service in Iraq. He had an inquiring mind and an imaginative flair for writing. A certain amount of anxiety about facing the blank page was normal for all writers, I assured him in our conversation. Nonetheless, he maintained, D. Andrews' work propelled him to envision the possibility of writing. Her work was purposeful and more closely approximated his own writing. Here are excerpts of his responses:

By using a student model, you made it more real...

We should look at professional models too because there is a reason Annie Dillard is held in such high regard. Still, most students, I think, feel they wouldn't be able to match a professional writer...it would be like me playing basketball with Michael Jordan...But, here it is like playing against a friend in high school who goes on to play on a professional team...

In reading the student model, I saw how purpose could be given to a piece. As I read her work, I was drawn to it, I cared about it, and I saw that she learned from it. I knew that is what I wanted to do... (Unpublished Student Responses from Semi-Structured Interview, April 2009) 
A close read of D. Andrews' model facilitated a central teaching objective I noted earlier, that students would integrate figurative or structural features of a text they admired. D. Andrews' essay begins with extracts of Shelley's poem, "The Sensitive Plant" and a quote by Keats (1816/1959): "The poetry of earth is never dead," (p. 19) paying homage to nature and orientating the reader to the world of the cocoon, the title of her piece. As Jerome had suggested, his peers were influenced positively by features of her work in their own writing, thereby writing what Murray (1989) calls "parallel texts." A number of students in the 2009 classroom began their creative non-fiction essays with a quote. The introduction in the model fired for them. When asked in journal and exam responses to reflect on what element resonated for them, students responded as follows:

I loved how D. Andrews introduced the paper using a quote...

I didn't initially think of it as student's work but something professionals would do... Starting out with the poem quote was bold-It was a bold step for a student to take, and I felt it was a great way to focus the piece. (Unpublished Student Responses from Exam and Journals, March-May 2009)

A second tool or strategy D. Andrews applied also surfaced in students' writing. With the collapsing time line in creative non-fiction, D. Andrews used asterisks. A number of students mimicked this feature to help organize their essays. Jerome referred to this problem-solving strategy on the final exam as he reflected on narrative elements which challenged him and took on new critical significance:

After my story began to come together, I was stuck on how to arrange it on the page. I had time lapses, and they needed to be noted somehow. Again, D. Andrews came to my rescue. I liked her simple strategy of using the asterisk for time and focus breaks, so I used the same method. I had no qualms about doing so, as her piece was presented to us as a way to learn. (Unpublished Student Response on Exam, May 2009)

A complex view of writing emerges. Students set goals and created an image of the task that depended upon the strategies they were learning (Flower, 1990). They then proceeded to write, integrating features of text that came before them in the discourse community of the creative non-fiction writing classroom (Bawarshi, 2003). With these features, they were applying newfound strategies in their own work. Since the model approximated their own writing, Vygotsky's zone of proximal development paved the way for learning, and for the individual agency and belief that generates writing, which I recognized in students' journal responses (Capra, 1996, 2002; Elbow, 1973). 
D. Andrews' narrative moved students emotionally and launched them into critical thinking about their own writing. A student further commented in her journal on the "great sensory detail that caught the reader's attention early in the piece" (Unpublished Student Response, April 2009). Another highlighted the angle of the piece, the cocoon, which provided the subject of the essay and unified it. Finding a subject, the student understood, was integral to the genesis of writing. In the following response, the student discovers his distinct writing subject even as he sets D's model alongside his own.

D's piece was incredibly helpful to me, as I saw how she was able to work a hook into her writing without it feeling artificial. I then started off to find my hook. I remembered the strong emotions connected with teaching my daughter to ride a bike. This was my hook. I had ridden my bike everywhere, and it is also a nearly universal event. Most children have their parents help them learn to ride their bike, and I wanted to tap into this common event as a point of reference for the reader. It closely matched D's cocoon idea, yet was not copying her idea. (Unpublished Student Exam Response, May 2009)

Another factor accounted for the success of the model. Because the student model's process was made more transparent to them, students were all the more drawn to the essay. While teaching the course that spring, I informed students about changes D. Andrews and I discussed in our one-on-one classroom conferences. For example, I relayed her need to fill in narrative gaps that were too abrupt for the reader (the details of which I will discuss shortly). In our semi-structured interview, Jerome mentioned this explicit part of my teaching because it elucidated for him what process could be and because it made the essay all the more accessible. In the next quote, Jerome is reading with a heightened awareness, like a writer (Prose, 2006) working with a curriculum where reading and writing were interdependent, where the two practices evolved in the "contrapuntal action" so necessary to the way writers work (Murray, 1989). Observing D. Andrews' thinking and writing processes as a model, Jerome was intent on adapting useful strategies for his own purposes (Halasek, 1999).

After my initial reaction to her piece, I really looked at her work and became more aware of the thinking behind the writing, of the plan she followed through. I was helped in this way when you said in class what her work looked like originally and when you gave us a description of her writing process. This really brought down the intimidation factor and allowed me to appreciate the process of writing. (Unpublished Student Responses from Semi-Structured Interview, April 2009) 
Let me now provide an excerpt from the first half of D. Andrews' essay, to which the students refer. In a piece of evocative writing that merges writer interacting with nature and family story, D. Andrews revisits her childhood fascination with living creatures. Her "hook" is established and her sensory detail replete. As a reliable narrator, she re-creates a child's sense of discovery and the self-satisfaction she felt about her new experiential knowledge.

My brother, Curtis and I were explorers within the confines of our backyard. We loved to see the small pieces of life that would otherwise be ignoredgrasshoppers, frogs, beetles, and the like. Curtis would even find small, skinny garden snakes and gently pick them up by the tail. We would look at the strange creature-Curt, from arm's length, and me from a slight distance. It would wriggle in the air awkwardly, contorting its slender body into a corkscrew as it was lowered delicately down to its familiar grassy territory. Once again on terra firma, its verdant form would slip into the grass and slither away, unharmed but grateful to be away from children's prying fingers. We would watch the spectacle, barely blinking.

It was in this spirit of discovery that we came upon the cocoon. It was a miracle of sorts, or at least that's how it seemed to us at the time: a brownishgray shape made of gauzy material, hanging innocently from a rail on our backyard fence.

"Mom!" we shouted, begging her to come outside. "Look close! You can see the caterpillar inside!"

“Well, look at that!" She smiled.

We were proud. We knew all about caterpillars and Cocoon.

Metamorphosis was a popular topic in elementary school science classes, so we felt especially qualified to observe the real-life experience. Over the next few weeks, we checked in on our bundled-up little friend every day. With time, the gauze over him began to thin and, when the cocoon became backlit by the sun, we could see the silhouette of tiny, premature wings. We longed for the day that the butterfly would come out, fully formed and ready to fly. I hoped we would watch the cocoon break open, to see a born-again creature emerging like a chick cracking its way out of an eggshell. (Unpublished Student Narrative, Summer 2009) 


\section{Reversal of Roles: Classroom Students Inform the Student Model Writer}

At this juncture, I shift the lens primarily toward the student classroom writers as editors of the student model essay. Attending to writers' concerns when reading the model, students subsequently contributed to D. Andrews' work with two important edits: in adding back story, and in her rewriting of the conclusion with more nuance and subtlety. Through this process of joint analysis, reflection, and revision, the exchange remained respectful. Students informally dialogued, had working conversations with text, with each other, and with me as they gained membership in a writing community of practice. In turn, the student model writer refined and embellished her piece as she met the needs of her audience.

\section{Adding back story.}

From my experience, revisions often entail filling in narrative gaps, thereby removing implausible shifts for the reader. During the fall semester, D. Andrews fastforwarded from the careless killing of the cocoon by her cousin Barry, a childhood playmate, to Barry's funeral, where she mourned the loss of his potential. Barry died tragically at nineteen. I informed her during our classroom conference in the fall that I was not emotionally invested enough to care about Barry's loss since I knew so little about the young man. Prompting her, I discovered that Barry had addictions and that he had sped-driven along a narrow town road, wrapping his car around a telephone pole. Armed with this information, I suggested a possible connection between the boy's casual disregard for nature and his carelessness about his own life. I was modeling for D. Andrews the kinds of connections writers make, finding a pattern of meaning upon which to thread a thematic motif through the narrative. She incorporated my feedback for more back story to a degree in her next version with moderately improved effect.

More was needed. D. Andrews would learn to fill breaks in the narrative with detail in order to achieve a more "satisfying and expressive relationship among the parts that constitute the whole" (Eisner, 2002, p. 75) and to win the credibility, empathy, and engagement of the reader.

In the Spring semester class, a student, Dave, echoed my need to know more about Barry in his quick write, but he expanded on my earlier response with specific questions, providing constructive feedback.

I would have liked to see more of a back story on Barry. What was he like in high school? What were his parents like? What is the author's opinion of what caused Barry to become this way and not like the author? These are 
questions that would make the story much more interesting. (Unpublished Student Quick Write [Journal] Response, April 2009)

I contacted D. Andrews via e-mail and informed her of the ongoing study of her narrative model. In the following response, D. Andrews addresses her readers' needs, readers who were "immediate participant[s]" (Bakhtin, 1986).

Thanks for sending the student comment. I'm so glad your spring students were interested and took time to offer feedback. It really is incredibly helpful. I have struggled with the idea of writing background.... know the story needs it, and it is part of my plan for my next revision. It's just one of those things that really needs to be handled delicately. (Unpublished Student E-mail Response, May 2009)

With time and distance and the respect afforded to her by peers, D. Andrews' tone was open and gracious. The interdependence among students who were not physically in the same classroom was evident to me. Here, too, D. Andrews acknowledges how challenging it is to find a balance in the rhetorical act of writing. We e-mailed one another on the need to inform readers enough while giving them ample room to make their own meaning. She voiced ethical concerns, as well, inherent to creative non-fiction, a genre where writers reveal truths about family and make public what is private. $\mathrm{D}$. Andrews was becoming more cognizant of the skill required to mediate with language when writing narratives about our fragile and precarious lives. School semester was now over, but our communication continued into the summer.

I'm trying to find a good balance between honesty and compassion. I feel like readers have to be a need-to-know basis, but at the same time, they need enough information to draw their own conclusions. It's a very fine line for me to write along. (Unpublished Student E-mail Response, June 2009)

As D. Andrews edited, she gained perspective on the narrative essay as a whole and on its details. She was discovering the piece she had to write (Bell, 2007). To compose the back story that my student, Dave, had recommended, one more element came into the complex mix - the realm of intuitive consciousness. Emotions intensify that consciousness and propel the writer to find a way to translate emotion into an aesthetic form (Hague, 2003). ${ }^{2}$ D. Andrews wrote to tell how she sensed it was time to write. Two years had passed since Barry's death. An anniversary of death loomed. 
A few days later, I received passages that met readers' needs for more detail without providing easy, succinct answers. She wrote about Barry's broad shoulders, his work ethic, how he would wake up before dawn to help a local dairy farmer with the morning milking, how the two of them graduated high school in their caps and gowns. Barry was now a more developed character with whom readers could empathize.

\section{b) Rewriting the conclusion.}

We learn on a continuum from our students. When my spring semester class read the conclusion of the essay, students remarked that $D$. Andrews had strained too hard for imagery, that the passage contained too many metaphors. I had somehow missed this, but my students alerted me to a further need for revision. In her symbolic effort to contrast herself from Barry, D. Andrews wrote:

There is however, a difference between a plant that blooms and one that shrivels into the shade; a monarch butterfly and a moth that flies into the hungry orange tongues of bonfire's flame. It is the signal an antenna reads from its own struggling body, the perception of self when the wings are tickled with a flame's taunting warmth. The moth either flies to the fire, or retreats into musty darkness. Given the chance, a butterfly leaves its cocoon. (Unpublished Student Narrative, Spring 2009)

In the role of intermediary, I e-mailed D. Andrews about the students' response, which was collective and unanimous. Evocative as the writing was, I could now see through my students' astute eyes and ears that the number of figurative devices blinded me, so that I didn't know which image to recall, which truth to hold on to. D. Andrews was highly receptive to the feedback, particularly after time had lapsed and the emotional and psychological distance between herself and her work gave her a clearer view of how the words impacted one another. She was also receiving this feedback from a community of peers, not from a reader who assessed her work quantitatively. The writing classroom became what Noddings (2002) calls an "artistic medium," a democratized shared process of inquiry where change was called for appropriate to the needs of the students at that point of their writing.

By mid-July, I heard back from D. Andrews. Her process was idiosyncratic and complex. She reenacted how she found the pieces of the puzzle by going back to the origins or impetus of the writing with the poem "The Sensitive Plant" for a key to the meaning she would make. That poem was a variable "along with the right state of mind, poor penmanship, and an expansion on the prior draft..." (Unpublished Student E-mail Response, July 2009). 
The last link of the narrative fed back into the first. In the excerpt below, the graduation brings the characters together. I present the final paragraph, which I suggest satisfies and illuminates without preaching, as the writer acknowledges the tenuousness of our lives.

Even now, we stand together in those pictures, smiling despite the uncertainty of where our lives are about to take us. We'll stay that way until, decades from now, the photographs age and yellow and decay. Until then, we remain in that moment when, despite any of life's injustices, we are together-linked inextricably to the great unknown promises the future has in store for us. Promises, which, in that moment, we each have a lifetime to fulfill. (Unpublished Student Narrative, Summer 2009)

\section{Educational Implications}

Alongside D. Andrews' noteworthy capacity as a writer is the inclusive dimension of the community of student readers and writers who depended on one another, who were inspired by her model essay, who integrated common elements from that essay into their own writing to good rhetorical effect, and who improved the model essay through their feedback over the course of time. Creativity was enhanced through the interchangeable roles students assumed as informed readers and writers.

Student classroom writers specifically benefited by the setting of goals and by writing with a keener sense of purpose; they gained from the hope they felt in approximating the student model; and they developed as writers from the figurative and structural features of the student model they included. In turn, the student model writer better solved challenges particular to the genre and to the trauma her narrative relayed through the feedback of student peers (in-class response) and teacher as facilitator (online).

Online feedback proved to be a viable teaching tool between myself and the student/model writer. While the student model writer assumed ownership, I facilitated by negotiating meaning when necessary and by offering suggestions as an informed reader. In examining this inquiry now, however, I envision a more visible role for a model student writer who could be brought into the class in real time, or could be incorporated, with that student writer's permission, more actively into the curriculum through technology. Students in the classroom could communicate their views and edits directly to the student model writer online through forums or blogging, for 
example. Why not open up online dialogues in a more recursive loop between student model writers (from former classes) and current students so that they construct meaning together and revise more effectively?

I end with Jerome's words as he looked back on the semester, on his building of writing strategies and burgeoning self-confidence. Jerome makes connections between his past learning and experience as he looks forward to the future quality of his writing. By accessing this student model in the structure and design of my curriculum, I left space enough for him to develop and create with the courage writing necessarily takes.

I feel now I am unafraid to take risks. I know that it is acceptable to push boundaries. I am also more able to piece smaller ideas into a larger theme. My writing is still in the toddler stage, but I feel I now have a framework to work with. (Unpublished Student Exam Response, May 2009)

\section{Notes}

1. Pseudonym.

2. Hague works with the Jungian concept of intuitive consciousness which she synthesizes and applies to the creative process.

\section{References}

Bakhtin, M. (1986). Speech genres and other late essays. Austin: University of Texas Press.

Barone, T. (2000). Aesthetics, politics and educational inquiry. New York: Peter Lang Publishing, Inc.

Bawarshi, A. (2003). Genre \& the invention of the writer. Logan: Utah State University Press.

Bell, S. (2007). The artful edit: On the practice of editing yourself. New York: W.W. Norton \& Company.
Capra, F. (1996). The web of life: A new scientific understanding of living systems. New York: Anchor Books.

Capra, F. (1999). Ecoliteracy: The challenge for education in the next century. Liverpool Schumacher Lectures. March 20, 1999. Berkeley: Center for Ecoliteracy.

Capra, F. (2002). The hidden connections: A science of sustainable living. New York: Anchor Books. 
Capra, F. (2004). Complexity and life. Audiorecording of seminar presented at Omega Institute, Institute for Holistic Studies. August 20, 2004. New York.

Dewey, J. (1938). Experience \& education. New York: Macmillan Publishing Company.

Eisner, E. (2002). The arts and the creation of the mind. New Haven: Yale University Press.

Elbow, P. (1973). Introduction. In Writing without Teachers. xi-xxxii. New York: OUP.

Flower, L. (1990). The role of task representation in reading-to-write. In Reading to write: Exploring a cognitive and social process. Linda Flower, Victoria Stein, John Ackerman, Margaret J. Kantz, Kathleen McCormick, \& Wayne C. Peck (Eds.) (pp. 35-75). New York: Oxford University Press.

Hague, A. (2003). Fiction, intuition, \& creativity: Studies in Bronte, James, Woolf, and Lessing. Washington: The Catholic University of America Press.

Halasek, K. (1999). A pedagogy of possibility: Bakhtinian perspectives on composition studies. Carbondale: Southern Illinois University Press.
Keats, J. (1816/1959). The grasshopper and the cricket. In Selected poems and letters (Ed. Douglas Bush). Boston: Houghton Mifflin Company.

Lipszyc, C. (2006). Self as journeyer: On writing and teaching paths. An arts-based autoethnographic study on the interconnectedness between writing and teaching. Doctorate of Education Dissertation, University of Toronto, Ontario Institute for Studies in Education.

Murray, D. M. (1989). Expecting the unexpected: Teaching myself - and others - to read and write. Portsmouth: Boynton/Cook Publishers Heinemann.

Noddings, N. (2002). Educating moral people: $A$ caring alternative to character education. New York: Teachers College Press.

Prose, F. (2006). Reading like a writer: A guide for people who have books and for those who want to write them. New York: Harper Collins.

Vygotsky, L. (1978). Interaction between learning and development. In Mind in Society. (Trans. M. Cole). Cambridge, MA: Harvard University Press.

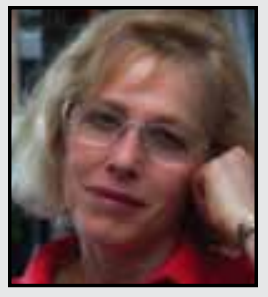

Carol Lipszyc is currently an Assistant Professor at State University of New York, Plattsburgh, teaching English teacher education and writing arts. Her book of lyrical and autobiographical poems, Singing Me Home, was published by Inanna Publications, York University, 2010. In 2011 and 2012, Carol published on arts-based and interdisciplinary education in Journal of Artistic and Creative Education and Complicity, an International Journal of Complexity and Education. Her Literacy/ ESL Reader with chants, People Express, was published by Oxford University Press, Toronto.

\section{LINKTO:}

http://www.carol-I.com

http://issuu.com/jaceonline/docs/jace-5-2-fa 